\title{
Interaction Effect between the Applied Phosphorus and Selenium with Time on Their Availability in Three Different Soil Types.
}

\author{
Heba, A. M. Abou-Zaid;*Hassan, H. Abas;** Mohamed, E. Ali** and Essam El-Deen, A.M.* \\ *Soils, Water and Environment Research Institute, Agricultural research Center, Giza, Egypt. \\ **Soils and Water Department, Moshtohor Agriculture Faculty, Benha University, Egypt. \\ Corresponding Author: drheba33@yahoo.com
}

\begin{abstract}
A laboratory experiment was conducted to evaluate the interaction effect of phosphorus and selenium application rates on their availability in three different soil types with time. The soil samples were collected from the surface layers "0-30 cm" of three different sites. Four levels from Se were used as followed $0.0-0.5$ 1.0 and $2.0 \mathrm{mg} \mathrm{Se} \mathrm{kg}^{-1}$ soil as sodium selenate while $\mathrm{P}$ was used as mono super phosphate at rates of $0.0-$ $3.225-6.45$ and $12.9 \mathrm{mg} \mathrm{P} \mathrm{kg}^{-1}$ soil and they were incubated with soil for one month. Results revealed a positive and significant correlation between Se and $\mathrm{P}$ application rates as well as time of incubation on soil available Se; where soil available Se content was increased with increasing the application rate of Se especially when $\mathrm{P}$ was also added at high rates as time of incubation was passed. The highest soil available Se values were obtained when Se and P were added at rates of 2 and $12.9 \mathrm{mg} \mathrm{kg}^{-1}$ soil, respectively especially in the case of soil 3 (clayey soil). Results also showed that soil available phosphorus was positively but not significant affected with increasing the application level of both Se and P, but it was negatively affected as the time of incubation was increased.
\end{abstract}

Key words: selenium, phosphorus, soil types, incubation.

\section{Introduction}

The element selenium (Se) was discovered by Swedish chemists J. J. Berzelius and J. G. Graham in 1817, who named it after the Greek moon goddess Selene. Although $\mathrm{Se}$ is not classified as an essential micronutrient for higher plants; selenium (Se) is considered as an essential micronutrient for humans and animals, but it is deficient in at least a billion people worldwide. Its deficiency in food can cause cancer, cardiovascular and other diseases in humans and animals, so it is used as a nutritional additive for livestock and poultry (Birringer et al., 2002).

Besides native substrate, amount of rainfall plays an important role in determining selenium content in soil. In regions with less than $500 \mathrm{~mm}$ of rain, the soil formed from rocks with a high Se content contains potentially toxic Se concentrations. The same kind of soil formed in humid regions typically contains high amounts of Se, but it is bound to iron in a poorly soluble complex. When the substrate is low in selenium, the soil forming on it will have a low Se concentration regardless of climate (Fleming, 1980).

Whereas some soils of the world are seleniferous, most are considered deficient. Soil is the major source of Se supply to humans and animals through food chains. The flux of Se from soil to humans is, to a large extent, determined by the content and availability of Se in the soils (Hartikainen, 2005). However, selenium reactivity, distribution and bioavailability depend not only on its total content in soil but also on its chemical forms and some soil factors such as soil reaction, soil salinity, calcium carbonate content, cation exchange capacity, organic matter content, aeration, contents of clay, the identity and concentration of competing ions, redox potential, content of sesquioxides and microbiological activity (Kabata-Pendias, 2001).

Selenium behavior in soils has received much attention in recent years. Selenium exists in the soil environment in four oxidation states: selenide, elemental selenium, selenite and selenate. Selenate is the predominant form of selenium in calcareous soils and under alkaline conditions but selenite is the predominant form in acidic soils (Kabata-Pendias and Mukherjee, 2007).

Because selenium can be in several interactions in the environment, its sorption behavior differs among soils, where the soil management or production systems are different (Lopes et al., 2017).

Vouri et al., (1989) noted that, 7 days after adding $5 \mathrm{mg} \mathrm{Se} \mathrm{kg}^{-1}$ soil as selenate, as much as $25 \%$ of the selenate was sorbed and that the amount was positively correlated with sulfuric acid-extractable phosphorus. Neal and Sposito (1989), however, did not find positive selenate adsorption onto four soils from the San Joaquin Valley, California.

Guo et al., (2000) found that transformation of Se was less affected by soil water content at $\geq 21.5 \%$, but was distinctively faster under anaerobic conditions where $\mathrm{O}_{2}$ was displaced with $\mathrm{N}_{2}$ gas. They also reported that during the incubation period of 49 to $52 \mathrm{~d}$, between 27.9 and $74.9 \%$ of the total selenium, initially present as selenate, was reduced to elemental or organic Se species.

El-Ghanam, (2004) found that soil available Se was significantly increased as the levels of selenium and phosphorus increased; the highest increase in soil available Se was occurred during the first period of incubation (15 days) where it amounted 35.3 and $130.8 \%$, as compared with $\mathrm{P}_{0}$ and $\mathrm{Se}_{0}$ treatments, 
respectively. Also, the soil available $\mathrm{P}$ was markedly increased with increasing the application rates of $\mathrm{P}$ and $\mathrm{Se}$, but it decreased as the incubation period increased.

Most studies such as Nakamaru et al., (2006) and Nakamaru and Sekine (2008) showed that Se becomes more plant available following phosphate addition, i.e. Se sorption decreases as phosphate increases.

El-Ramady et al., (2014) showed that sandy soils have lower Se contents compared to organic and calcareous soils.

Li et al., (2016) showed that the change of soil available $\mathrm{Se}$ in all tested soils divided into two phases: rapid decrease at the initial time (42 days) and slow decline thereafter. The second order equation could describe the decrease processes of available $\mathrm{Se}$ in tested soils during the entire incubation time $(\mathrm{R} 2>0.99)$, while parabolic diffusion equation had less goodness of fit. These results indicated that Se aging was controlled not only by diffusion process but also by other processes such as nucleation/precipitation, adsorption/ desorption with soil component, occlusion by organic matter and reduction reaction. Soil available Se fractions tended to transform to more stable fractions during aging.

\section{Materials and Methods}

A laboratory experiment was conducted to evaluate the interaction effect of phosphorus and selenium application rates on Se availability in three different soil types with time. The soil samples were collected from the surface layers "0-30 $\mathrm{cm}$ " of three different sites i.e. soil (1) was presented from ElAreesh Agricultural Research Station, North Sainai governorate, Egypt, soil (2) was collected from ElNobarya Agricultural Research Station, Al-Behaira governorate, Egypt and soil (3) was presented from Bahteem Agricultural Research Station, El-Qalubia governorate, Egypt. Soil samples were air dried at room temperature and grounded to pass through a $2 \mathrm{~mm}$ sieve. Four levels from Se were added as followed $0.0-0.5-1.0$ and $2.0 \mathrm{mg} \mathrm{Se} \mathrm{kg}^{-1}$ soil as sodium selenate while $\mathrm{P}$ was used as mono super phosphate at rates of $0.0-3.225-6.45$ and $12.9 \mathrm{mg}$ $\mathrm{P} \mathrm{kg}^{-1}$ soil which equivalent $0.0-119-238$ and 476 $\mathrm{kg}$ fertilizer $\mathrm{ha}^{-1}$. Plastic cubs were filled with the sieved soils at a rate of $300 \mathrm{~g}$ from soil (1) and $200 \mathrm{~g}$ from both of soils (2) and (3). Super phosphate was added and mixed with soil in each cub then selenium solution was added at a rate of $80 \%$ from field capacity of each soil type. The experiment was conducted for one month, through this period soils were kept moisted to $80 \%$ of the field capacity by adding the distilled water. Each treatment was represented by five replicates which were arranged in a completely randomized design (CRD); one of them was taken after one day, three days, one week, two weeks and the last one was taken after one month from the beginning of the experiment.

Table 1. Characteristics of the soils used in the study.

\begin{tabular}{|c|c|c|c|c|c|c|c|c|c|c|}
\hline \multicolumn{11}{|c|}{ Soil (1) } \\
\hline Sand & $\begin{array}{l}\text { Silt } \\
\%\end{array}$ & Clay & \multirow{3}{*}{$\begin{array}{c}\text { Texture class } \\
\text { Sandy }\end{array}$} & $\mathrm{pH}(1: 2.5)$ & \multicolumn{3}{|c|}{$\mathrm{EC}(1: 5) \mathrm{dS} \mathrm{m}^{-1}$} & Organic matter & \multicolumn{2}{|c|}{$\mathrm{CaCO}_{3}$} \\
\hline 94.6 & 4.1 & 1.3 & & 7.65 & & 0.17 & & 5.2 & & \\
\hline \multicolumn{8}{|c|}{ Soluble ions $\left(\right.$ mmole $\left.^{-1}\right)$ and SAR } & & \multicolumn{2}{|c|}{ Available elements $\left(\mathrm{mg} \mathrm{kg}^{-1}\right)$} \\
\hline $\mathrm{Ca}^{++}$ & $\mathrm{Mg}^{++}$ & $\mathrm{K}^{+}$ & $\mathrm{Na}^{+}$ & $\mathrm{HCO}_{3}{ }^{-}$ & $\mathrm{CO}_{3}^{--}$ & $\mathrm{Cl}^{-}$ & $\mathrm{SO}_{4}^{--}$ & SAR & $\mathrm{P}$ & $\mathrm{Se}$ \\
\hline 0.42 & 0.23 & 0.12 & 0.82 & 0.10 & Nil & 0.67 & 0.82 & 1.44 & 6.47 & 0.038 \\
\hline \multicolumn{11}{|c|}{ Soil (2) } \\
\hline Sand & $\begin{array}{l}\text { Silt } \\
\%\end{array}$ & Clay & \multirow{2}{*}{$\begin{array}{c}\text { Texture class } \\
\text { Sandy clay } \\
\text { loam }\end{array}$} & $\mathrm{pH}(1: 2.5)$ & \multicolumn{3}{|c|}{$\mathrm{EC}(1: 5) \mathrm{dS} \mathrm{m}^{-1}$} & Organic matter & \multicolumn{2}{|c|}{$\mathrm{CaCO}_{3}$} \\
\hline 62.7 & 24.3 & 13.0 & & 8.47 & \multicolumn{3}{|c|}{1.07} & 7.1 & \multicolumn{2}{|c|}{257.0} \\
\hline \multicolumn{9}{|c|}{ Soluble ions $\left(\mathrm{mmole} \mathrm{L}^{-1}\right)$ and SAR } & \multicolumn{2}{|c|}{ Available elements ( $\left.\mathrm{mg} \mathrm{kg}^{-1}\right)$} \\
\hline $\mathrm{Ca}^{++}$ & $\mathrm{Mg}^{++}$ & $\mathrm{K}^{+}$ & $\mathrm{Na}^{+}$ & $\mathrm{HCO}_{3}^{-}$ & $\mathrm{CO}_{3}^{--}$ & $\mathrm{Cl}^{-}$ & $\mathrm{SO}_{4}^{--}$ & SAR & $\mathrm{P}$ & $\mathrm{Se}$ \\
\hline 3.32 & 2.36 & 1.42 & 3.22 & 0.20 & Nil & 7.84 & 2.28 & 1.91 & 5.66 & 0.064 \\
\hline \multicolumn{11}{|c|}{ Soil (3) } \\
\hline Sand & $\begin{array}{l}\text { Silt } \\
\%\end{array}$ & Clay & \multirow{2}{*}{$\begin{array}{l}\text { Texture class } \\
\text { Clay }\end{array}$} & $\mathrm{pH}(1: 2.5)$ & \multicolumn{3}{|c|}{$\mathrm{EC}(1: 5) \mathrm{dS} \mathrm{m}^{-1}$} & Organic matter & \multicolumn{2}{|c|}{$\mathrm{CaCO}_{3}$} \\
\hline 7.3 & 20.2 & 72.5 & & \multicolumn{4}{|c|}{$\begin{array}{c}7.55 \\
\text { oluble ions }\left(\mathrm{mmole}^{-1}\right) \text { and SAR }\end{array}$} & 18.4 & \multicolumn{2}{|c|}{$\begin{array}{c}26.4 \\
\text { Available elements }\left(\mathrm{mg} \mathrm{kg}^{-1}\right)\end{array}$} \\
\hline $\mathrm{Ca}^{++}$ & $\mathrm{Mg}^{++}$ & $\mathrm{K}^{+}$ & $\mathrm{Na}^{+}$ & $\mathrm{HCO}_{3}^{-}$ & $\mathrm{CO}_{3}^{--}$ & $\mathrm{Cl}^{-}$ & $\mathrm{SO}_{4}^{--}$ & SAR & $\mathrm{P}$ & $\mathrm{Se}$ \\
\hline 0.58 & 0.32 & 0.36 & 0.65 & 0.10 & Nil & 1.21 & 0.60 & 1.56 & 15.73 & 0.068 \\
\hline
\end{tabular}

The soils chemical analyses were performed according with the methodology by Sadzawka et al., (2004). Briefly, soil $\mathrm{pH}$ was assayed by potentiometer in a 1:2.5 (w/v) soil/distilled water suspension. Electrical conductivity EC $\left(\mathrm{dSm}^{-1}\right.$ at 25 C) was determined in 1:5 (soil/water) extract, using EC meter, as described by Jackson, (1973). Organic matter was determined by wet digestion with a modified Walkley and Black method. Soluble ions and calcium carbonate content were determined as described by Page et al., (1982). Available phosphorus was extracted by the Olsen bicarbonate method and analyzed colorimetrically using ascorbic acid according to Murphy and Riley, (1962) as 
modified by John, (1970). Available selenium was extracted using ammonium bicarbonate - DTPA solution as described by Soltanpour and Workman, (1980) and measured by Atomic Absorption Spectrophotometry - Hydride Generation coupled (AAS-HG) according to Kumpulainen et al., (1983).

Results and Discussion

Soil available selenium.
Data presented in table 2 revealed that there were no significant differences between treatments in available $\mathrm{Se}$ values, where the available $\mathrm{Se}$ was increased with increasing $\mathrm{Se}$ application rates especially when Se was added at a rate of $2 \mathrm{mg} \mathrm{kg}^{-1}$ soil, but this increasing was not significant. These results were in accordance with those of ElGhanam, (2004) who reported that soil available Se

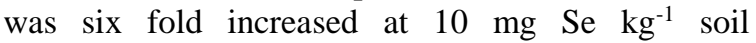
compared with 0 level, then increased to thirteen fold as Se level was increased to $40 \mathrm{mg} \mathrm{Se} \mathrm{kg}^{-1}$ soil.

Table 2. AB-DTPA extractable Se $\left(\mathrm{mg} \mathrm{kg}^{-1}\right)$ as affected by selenium and phosphorus application rates as well as incubation periods.

\begin{tabular}{|c|c|c|c|c|c|c|c|}
\hline \multirow{3}{*}{$\begin{array}{l}\text { Phosphorus rates } \\
\qquad\left(\mathrm{mg} \mathrm{kg}^{-1}\right)\end{array}$} & \multirow{3}{*}{$\begin{array}{l}\text { Selenium rates } \\
\quad\left(\mathrm{mg} \mathrm{kg}^{-1}\right)\end{array}$} & \multicolumn{6}{|c|}{ Soil (1) sandy } \\
\hline & & \multicolumn{6}{|c|}{ Time } \\
\hline & & $\mathrm{T} 1$ & T 2 & T 3 & $\mathrm{~T} 4$ & T 5 & Mean \\
\hline \multirow{4}{*}{ P $1(0.00)$} & Se $1(0.0)$ & 0.038 & 0.034 & 0.036 & 0.040 & 0.038 & 0.037 \\
\hline & Se $2(0.5)$ & 0.062 & 0.066 & 0.070 & 0.072 & 0.076 & 0.069 \\
\hline & Se $3(1.0)$ & 0.094 & 0.104 & 0.108 & 0.110 & 0.114 & 0.106 \\
\hline & Se $4(2.0)$ & 0.126 & 0.130 & 0.138 & 0.134 & 0.138 & 0.133 \\
\hline \multicolumn{2}{|c|}{ Mean } & 0.080 & 0.084 & 0.088 & 0.089 & 0.092 & \\
\hline \multicolumn{2}{|c|}{ Grand mean of phosphorus rates } & 0.087 & & & & & \\
\hline \multirow{4}{*}{ P $2(3.225)$} & Se $1(0.0)$ & 0.052 & 0.052 & 0.054 & 0.056 & 0.062 & 0.055 \\
\hline & Se $2(0.5)$ & 0.086 & 0.090 & 0.092 & 0.088 & 0.092 & 0.090 \\
\hline & Se $3(1.0)$ & 0.122 & 0.125 & 0.126 & 0.130 & 0.138 & 0.128 \\
\hline & Se $4(2.0)$ & 0.168 & 0.170 & 0.174 & 0.182 & 0.184 & 0.176 \\
\hline \multicolumn{2}{|c|}{ Mean } & 0.107 & 0.109 & 0.112 & 0.114 & 0.119 & \\
\hline \multicolumn{2}{|c|}{ Grand mean of phosphorus rates } & 0.112 & & & & & \\
\hline \multirow{4}{*}{ P3 (6.45) } & Se $1(0.0)$ & 0.066 & 0.068 & 0.072 & 0.072 & 0.074 & 0.070 \\
\hline & Se $2(0.5)$ & 0.088 & 0.094 & 0.096 & 0.096 & 0.097 & 0.094 \\
\hline & Se $3(1.0)$ & 0.156 & 0.162 & 0.171 & 0.174 & 0.176 & 0.168 \\
\hline & $\operatorname{Se} 4(2.0)$ & 0.174 & 0.174 & 0.178 & 0.182 & 0.184 & 0.178 \\
\hline \multicolumn{2}{|c|}{ Mean } & 0.121 & 0.124 & 0.129 & 0.131 & 0.133 & \\
\hline \multicolumn{2}{|c|}{ Grand mean of phosphorus rates } & 0.128 & & & & & \\
\hline \multirow{4}{*}{ P 4 (12.9) } & Se $1(0.0)$ & 0.072 & 0.075 & 0.080 & 0.082 & 0.086 & 0.079 \\
\hline & Se $2(0.5)$ & 0.094 & 0.096 & 0.102 & 0.105 & 0.109 & 0.101 \\
\hline & Se $3(1.0)$ & 0.172 & 0.178 & 0.180 & 0.184 & 0.190 & 0.181 \\
\hline & Se $4(2.0)$ & 0.196 & 0.198 & 0.194 & 0.196 & 0.201 & 0.197 \\
\hline \multicolumn{2}{|c|}{ Mean } & 0.134 & 0.137 & 0.139 & 0.142 & 0.147 & \\
\hline \multicolumn{2}{|c|}{ Grand mean of phosphorus rates } & 0.140 & & & & & \\
\hline \multirow{2}{*}{\multicolumn{2}{|c|}{ Grand mean of selenium rates }} & Se 1 & Se 2 & \multicolumn{2}{|c|}{ Se 3} & \multicolumn{2}{|c|}{$\mathrm{Se} 4$} \\
\hline & & 0.043 & 0.089 & \multicolumn{2}{|c|}{0.139} & \multicolumn{2}{|c|}{0.190} \\
\hline \multicolumn{2}{|c|}{ Selenium rates $\left(\mathrm{mg} \mathrm{kg}^{-1}\right)$} & $\mathrm{T} 1$ & T 2 & T 3 & $\mathrm{~T} 4$ & \multicolumn{2}{|c|}{ T 5} \\
\hline \multicolumn{2}{|c|}{ Se $1(0.0)$} & 0.041 & 0.043 & 0.044 & 0.045 & & \\
\hline Se 2 & & 0.088 & 0.092 & 0.090 & 0.086 & & \\
\hline Se 3 & & 0.136 & 0.140 & 0.141 & 0.137 & & \\
\hline $\mathrm{Se} 4$ & & 0.190 & 0.192 & 0.182 & 0.192 & & \\
\hline Grand me & of time & 0.113 & 0.116 & 0.114 & 0.115 & & \\
\hline & & & at $5 \%$ & & & & \\
\hline Selenium & es (Se) & & & 0.00 & & & \\
\hline Phosphoru & ates $(\mathrm{P})$ & & & 0.0( & & & \\
\hline Interactio & Se x P) & & & 0.00 & & & \\
\hline Tim & & & & 0.00 & & & \\
\hline Interactio & Se x T) & & & 0.0( & & & \\
\hline Interactio & $(\mathrm{P} \times \mathrm{T})$ & & & 0.00 & & & \\
\hline Interaction & x $\mathrm{P} \times \mathrm{T})$ & & & 0.00 & & & \\
\hline
\end{tabular}

T1 = one day $\quad$ T2 = three days $\quad$ T3 = one week $\quad$ T4 = two weeks $\quad$ T5 = one month 
Table 2. cont.

\begin{tabular}{|c|c|c|c|c|c|c|c|}
\hline \multirow{3}{*}{$\begin{array}{l}\text { Phosphorus rates } \\
\quad\left(\mathrm{mg} \mathrm{kg}^{-1}\right)\end{array}$} & \multirow{3}{*}{$\begin{array}{l}\text { Selenium rates } \\
\quad\left(\mathrm{mg} \mathrm{kg}^{-1}\right)\end{array}$} & \multicolumn{6}{|c|}{ Soil (2) sandy clay loam } \\
\hline & & \multicolumn{6}{|c|}{ Time } \\
\hline & & T1 & $\mathrm{T} 2$ & T 3 & $\mathrm{~T} 4$ & T 5 & Mean \\
\hline \multirow{4}{*}{ P $1(0.00)$} & Se $1(0.0)$ & 0.043 & 0.044 & 0.046 & 0.044 & 0.046 & 0.045 \\
\hline & Se $2(0.5)$ & 0.074 & 0.074 & 0.078 & 0.080 & 0.084 & 0.078 \\
\hline & Se $3(1.0)$ & 0.132 & 0.134 & 0.134 & 0.138 & 0.140 & 0.136 \\
\hline & Se $4(2.0)$ & 0.146 & 0.147 & 0.151 & 0.154 & 0.157 & 0.151 \\
\hline \multicolumn{2}{|c|}{ Mean } & 0.099 & 0.100 & 0.102 & 0.104 & 0.107 & \\
\hline \multicolumn{2}{|c|}{ Grand mean of phosphorus rates } & 0.102 & & & & & \\
\hline \multirow{4}{*}{ P $2(3.225)$} & Se $1(0.0)$ & 0.064 & 0.066 & 0.070 & 0.076 & 0.082 & 0.072 \\
\hline & Se $2(0.5)$ & 0.090 & 0.094 & 0.096 & 0.098 & 0.104 & 0.096 \\
\hline & Se $3(1.0)$ & 0.150 & 0.154 & 0.152 & 0.156 & 0.160 & 0.154 \\
\hline & $\operatorname{Se} 4(2.0)$ & 0.188 & 0.192 & 0.196 & 0.204 & 0.211 & 0.198 \\
\hline \multicolumn{2}{|c|}{ Mean } & 0.123 & 0.127 & 0.129 & 0.134 & 0.139 & \\
\hline \multicolumn{2}{|c|}{ Grand mean of phosphorus rates } & 0.130 & & & & & \\
\hline \multirow{4}{*}{ P3 (6.45) } & Se $1(0.0)$ & 0.080 & 0.084 & 0.082 & 0.086 & 0.094 & 0.085 \\
\hline & Se $2(0.5)$ & 0.094 & 0.098 & 0.104 & 0.107 & 0.110 & 0.103 \\
\hline & Se $3(1.0)$ & 0.164 & 0.166 & 0.172 & 0.182 & 0.186 & 0.174 \\
\hline & $\operatorname{Se} 4(2.0)$ & 0.220 & 0.226 & 0.228 & 0.234 & 0.236 & 0.229 \\
\hline \multicolumn{2}{|c|}{ Mean } & 0.139 & 0.144 & 0.147 & 0.152 & 0.156 & \\
\hline \multicolumn{2}{|c|}{ Grand mean of phosphorus rates } & 0.148 & & & & & \\
\hline \multirow{4}{*}{ P 4 (12.9) } & Se $1(0.0)$ & 0.084 & 0.085 & 0.088 & 0.092 & 0.096 & 0.089 \\
\hline & $\operatorname{Se} 2(0.5)$ & 0.106 & 0.111 & 0.116 & 0.122 & 0.124 & 0.116 \\
\hline & Se $3(1.0)$ & 0.182 & 0.184 & 0.188 & 0.190 & 0.196 & 0.188 \\
\hline & $\mathrm{Se} 4(2.0)$ & 0.242 & 0.246 & 0.254 & 0.266 & 0.274 & 0.256 \\
\hline \multicolumn{2}{|c|}{ Mean } & 0.154 & 0.157 & 0.162 & 0.168 & 0.173 & \\
\hline \multicolumn{2}{|c|}{ Grand mean of phosphorus rates } & 0.163 & & & & & \\
\hline \multirow{2}{*}{\multicolumn{2}{|c|}{ Grand mean of selenium rates }} & $\mathrm{Se} 1$ & $\mathrm{Se} 2$ & \multicolumn{2}{|c|}{ Se 3} & \\
\hline & & 0.052 & 0.106 & \multicolumn{2}{|c|}{0.152} & \multicolumn{2}{|c|}{0.232} \\
\hline \multicolumn{2}{|c|}{ Selenium rates $\left(\mathrm{mg} \mathrm{kg}^{-1}\right)$} & $\mathrm{T} 1$ & T 2 & Т 3 & $\mathrm{~T} 4$ & \multicolumn{2}{|c|}{$\mathrm{T} 5$} \\
\hline \multicolumn{2}{|c|}{ Se $1(0.0)$} & 0.048 & 0.051 & 0.052 & 0.054 & & \\
\hline Se 2 & & 0.161 & 0.095 & 0.091 & 0.092 & & \\
\hline Se 3 & & 0.153 & 0.155 & 0.143 & 0.153 & & \\
\hline $\mathrm{Se} 4$ & $.0)$ & 0.223 & 0.230 & 0.237 & 0.244 & & \\
\hline Grand me & of time & 0.146 & 0.132 & 0.130 & 0.135 & & \\
\hline & & & at $5 \%$ & & & & \\
\hline Selenium & tes $(\mathrm{Se})$ & & & & & & \\
\hline Phosphor & rates $(\mathrm{P})$ & & & & & & \\
\hline Interactic & $(\operatorname{Se} \times \mathrm{P})$ & & & & & & \\
\hline Tim & & & & & & & \\
\hline Interactio & Se $x \mathrm{~T})$ & & & & & & \\
\hline Interactic & $(\mathrm{P} \times \mathrm{T})$ & & & & & & \\
\hline Interaction & ( $x(\mathrm{P} \times \mathrm{T})$ & & & & & & \\
\hline
\end{tabular}

High significant differences in available Se were observed in the case of soil3 (clay) when it was compared with the two other used soils. This may be due to its highly content of clay and consequently its high cation exchange capacity. These findings were in agreement with the results obtained by ElRamady et al., (2014) who mentioned that sandy soils have lower Se contents compared with organic and calcareous soils; and Lessa, et al., (2016) who found that the Se adsorption was greater in the clayey soils compared with sandy ones due to its high content of clay and consequently high cation exchange capacity.
With respect to phosphorus application rates, results also revealed that there were no significant differences between treatments in available Se values where the available Se was increased with increasing the application rate of $\mathrm{P}$, especially when $\mathrm{P}$ was added at a rate of $12.9 \mathrm{mg} \mathrm{kg}^{-1}$ soil however this increasing was not significant. These results were in agreement to some extent with those of El-Ghanam (2004) who showed that AB-DTPA extractable Se increased significantly with increasing $\mathrm{P}$ application rate. Also, the increase in available $\mathrm{Se}$ may be ascribed to that certain anions such as phosphate, silicate, citrate, molybdate, carbonate, fluoride and sulfate which are compete with selenate for 
adsorption sites and reduce its fixation in soils. Masanza et al. (2016) also reported that phosphorus ions in the soil solution are readily adsorb on the sorptive surface of soil colloidal particles thus decreasing the sorption of Se on the soil surface and increasing the bioavailability of Se.

Regarding to the interaction between $\mathrm{Se}$ and $\mathrm{P}$, the obtained results showed that there were a positive and significant correlation between $\mathrm{Se}$ and $\mathrm{P}$ application rates on available $\mathrm{Se}$, where its available content was increased with increasing the application rate of Se especially when $\mathrm{P}$ was also added at high rates. The highest soil available $\mathrm{Se}$ value was obtained when Se and $\mathrm{P}$ were added at rates of 2 and $12.9 \mathrm{mg} \mathrm{kg}^{-1}$ soil, respectively. The highly available Se value was obtained with soil 3 , this may as previously mentioned be resulted from its highly clay content and high CEC of it compared with the two other used soils as mentioned previously by (ElRamady et al., 2014).

Table 2: con.

\begin{tabular}{|c|c|c|c|c|c|c|c|}
\hline \multirow{2}{*}{$\begin{array}{l}\text { Phosphorus rates } \\
\text { (mg kg-1 soil) }\end{array}$} & \multirow{2}{*}{$\begin{array}{l}\text { Selenium rates } \\
\left(\mathrm{mg} \mathrm{kg}^{-1} \text { soil }\right)\end{array}$} & \multicolumn{6}{|c|}{$\begin{array}{l}\text { Soil (3) clay } \\
\text { Time }\end{array}$} \\
\hline & & $\mathrm{T} 1$ & $\mathrm{~T} 2$ & T 3 & $\mathrm{~T} 4$ & T 5 & Mean \\
\hline \multirow{4}{*}{ P $1(0.00)$} & Se $1(0.0)$ & 0.068 & 0.074 & 0.070 & 0.074 & 0.074 & 0.072 \\
\hline & Se $2(0.5)$ & 0.124 & 0.130 & 0.132 & 0.136 & 0.134 & 0.131 \\
\hline & Se $3(1.0)$ & 0.178 & 0.186 & 0.190 & 0.186 & 0.190 & 0.186 \\
\hline & Se $4(2.0)$ & 0.242 & 0.250 & 0.254 & 0.262 & 0.266 & 0.255 \\
\hline \multicolumn{2}{|c|}{ Mean } & 0.153 & 0.160 & 0.162 & 0.165 & 0.166 & \\
\hline \multicolumn{2}{|c|}{ Grand mean of phosphorus rates } & 0.161 & & & & & \\
\hline \multirow{4}{*}{ P $2(3.225)$} & Se $1(0.0)$ & 0.080 & 0.084 & 0.084 & 0.090 & 0.096 & 0.087 \\
\hline & Se $2(0.5)$ & 0.136 & 0.136 & 0.142 & 0.146 & 0.150 & 0.142 \\
\hline & Se $3(1.0)$ & 0.182 & 0.186 & 0.190 & 0.194 & 0.190 & 0.188 \\
\hline & Se $4(2.0)$ & 0.250 & 0.260 & 0.266 & 0.274 & 0.270 & 0.264 \\
\hline \multicolumn{2}{|c|}{ Mean } & 0.162 & 0.166 & 0.170 & 0.176 & 0.177 & \\
\hline \multicolumn{2}{|c|}{ Grand mean of phosphorus rates } & 0.170 & & & & & \\
\hline \multirow{4}{*}{ P3 (6.45) } & Se $1(0.0)$ & 0.094 & 0.098 & 0.104 & 0.106 & 0.112 & 0.103 \\
\hline & Se $2(0.5)$ & 0.130 & 0.134 & 0.132 & 0.136 & 0.144 & 0.135 \\
\hline & Se $3(1.0)$ & 0.186 & 0.190 & 0.194 & 0.198 & 0.194 & 0.192 \\
\hline & Se $4(2.0)$ & 0.256 & 0.270 & 0.274 & 0.274 & 0.286 & 0.272 \\
\hline \multicolumn{2}{|c|}{ Mean } & 0.166 & 0.173 & 0.176 & 0.179 & 0.184 & \\
\hline \multicolumn{2}{|c|}{ Grand mean of phosphorus rates } & 0.176 & & & & & \\
\hline \multirow{4}{*}{ P 4 (12.9) } & Se $1(0.0)$ & 0.104 & 0.112 & 0.114 & 0.118 & 0.118 & 0.113 \\
\hline & Se $2(0.5)$ & 0.138 & 0.142 & 0.146 & 0.150 & 0.154 & 0.146 \\
\hline & Se $3(1.0)$ & 0.190 & 0.194 & 0.201 & 0.204 & 0.208 & 0.199 \\
\hline & $\operatorname{Se} 4(2.0)$ & 0.269 & 0.276 & 0.290 & 0.290 & 0.304 & 0.286 \\
\hline \multicolumn{2}{|c|}{ Mean } & 0.175 & 0.181 & 0.188 & 0.191 & 0.196 & \\
\hline \multicolumn{2}{|c|}{ Grand mean of phosphorus rates } & 0.186 & & & & & \\
\hline \multirow{2}{*}{\multicolumn{2}{|c|}{ Grand mean of selenium rates }} & Se 1 & Se 2 & \multicolumn{2}{|c|}{ Se 3} & \multicolumn{2}{|c|}{$\mathrm{Se} 4$} \\
\hline & & 0.074 & 0.130 & \multicolumn{2}{|c|}{0.190} & \multicolumn{2}{|c|}{0.269} \\
\hline \multicolumn{2}{|c|}{ Selenium rates $\left(\mathrm{mg} \mathrm{kg}^{-1}\right)$} & $\mathrm{T} 1$ & T 2 & $\mathrm{~T} 3$ & $\mathrm{~T} 4$ & \multicolumn{2}{|c|}{ T 5} \\
\hline \multicolumn{2}{|c|}{ Se $1(0.0)$} & 0.072 & 0.077 & 0.072 & $0.072 \mathrm{q}$ & \multicolumn{2}{|c|}{0.076} \\
\hline Se 2 & & 0.127 & 0.131 & 0.128 & 0.1301 & & \\
\hline Se 3 & & 0.184 & 0.189 & 0.191 & $0.193 \mathrm{f}$ & & \\
\hline Se 4 & & 0.252 & 0.264 & 0.271 & $0.275 \mathrm{~b}$ & & \\
\hline Grand me & of time & 0.159 & 0.165 & 0.166 & $0.167 \mathrm{~b}$ & & \\
\hline & & & at $5 \%$ & & & & \\
\hline Selenium & tes $(\mathrm{Se})$ & & & & & & \\
\hline Phosphor & rates $(\mathrm{P})$ & & & & & & \\
\hline Interactio & Se x P) & & & & & & \\
\hline Tim & & & & & & & \\
\hline Interactio & Se $x \mathrm{~T})$ & & & & & & \\
\hline Interactic & $(\mathrm{P} \times \mathrm{T})$ & & & & & & \\
\hline Interaction & $(\mathrm{x} \times \mathrm{P})$ & & & & & & \\
\hline
\end{tabular}

\begin{tabular}{lllll}
\hline T1 = one day & T2 $=$ three days & T3 $=$ one week & T4 $=$ two weeks & T5 = one month
\end{tabular}

For time, our results showed that available $\mathrm{Se}$ was increased with time passed this may be due to replacement of $\mathrm{Se}$ with $\mathrm{P}$ on the exchangeable sites of all the three soils used in the study. This process may be made Se more labile and consequently more available in soil solution. This is in accordance with 
results of El-Ghanam, (2004) who mentioned that the available $\mathrm{Se}$ was significantly increased prolonging the incubation periods 15 to 30,30 to 45 and 45 to 60 days by $28.6,47.1$ and $74.2 \%$, respectively.

With respect to the interaction between time and Se application rate the obtained results revealed that available Se was increased with increasing Se application rates and time; where available Se was increased in the end of the experiment, i.e. after one month according to (Masanza et al., 2016).

Regarding to the interaction effect of phosphorus application rates and time on the availability of selenium, the obtained data showed that the available Se was increased with increasing $\mathrm{P}$ application rate and also with time passed. This may be as previously mentioned due to replacement process between $\mathrm{P}$ and Se on the exchangeable sites especially in the case of the second soil (sandy clay loam) due to its high content from calcium carbonate and consequently high CEC when compared as previously mentioned with the two other soils used in the study.

Finally, regarding to the interaction effect between phosphorus and selenium application rates and time, the obtained results showed that the availability of Se was increased with increasing $\mathrm{P}$ and Se application rates as well as with time passed due, as previously mentioned, to replacement of Se with $\mathrm{P}$ on the soil adsorption sites especially in the case of the second soil. These findings were in agreement with results of Eich-Greatorex et al., (2010) who reported that available Se was increased with increasing the application rates of both Se and $\mathrm{P}$ prolonging the period of incubation especially in silty clay loam soil due to adsorption of $\mathrm{P}$ immediately on the surface of colloidal particles of soil thus render Se more free in soil solution. They also mentioned that after 60 days of incubation approximately $95 \%$ of the applied $\mathrm{P}$ was adsorbed on soil surface and gradually rendered the free $\mathrm{Se}$ available in soil solution.

\section{Soil available phosphorus.}

Results presented in table 3 revealed that there was significant effect of $\mathrm{P}$ application rate on the available phosphorus. This finding was in accordance with the results of El-Ghanam, (2004) who mentioned that available $\mathrm{P}$ was increased with increasing $\mathrm{P}$ application level compared with control treatment.

The obtained results also showed that available phosphorus was increased with increasing selenium application level especially when Se was added at a rate of $2 \mathrm{mg} \mathrm{kg}^{-1}$ but generally this increasing was not significant. These results were in accordance with those of Eich-Greatorex et al., (2010) who reported that Se addition, especially in form of selenate resulted in a higher release of phosphate from soils with high $\mathrm{P}$ saturation values compared to low levels.

With regard to the interaction effect between Se and $\mathrm{P}$ application rates on available phosphorus, results showed that available $\mathrm{P}$ was positively but not significant affected with increasing the application level of both Se and P. These results agree well with those obtained by El-Ghanam, (2004).

Regarding to time, the obtained results revealed that available $\mathrm{P}$ was decreased with time pass, this may be as expected due to fixation and precipitation processes which converted the available $\mathrm{P}$ to unavailable form with time; this was more clearly in the case of soil 2 where its content of calcium carbonate was high compared with the two other used soils. These are similar to those of El-Gala et al., (1998) who found that soil available $\mathrm{P}$ was decreased with increasing incubation time in calcareous soil.

The interaction effect between $\mathrm{P}$ application level and time reflected the decreasing in available $\mathrm{P}$ values with time even though when $\mathrm{P}$ was added at high rate i.e. $12.9 \mathrm{mg} \mathrm{kg}^{-1}$ soil. This may be confirm the fact that phosphorus converted to unavailable form with time pass as a result to fixation and precipitation processes as previously mentioned according to Eich-Greatorex et al., (2010).

Concerning the interaction effect between Se and time on available $\mathrm{P}$, results showed that available $\mathrm{P}$ was increased with increasing selenium application rate but it decreased with increasing the period of incubation, but it was increased again genteelly in the end of experiment i.e. after one month from the beginning of the incubation trial. These results were in accordance with these obtained by El-Ghanam, (2004) who reported that soil available $P$ was markedly increased with increasing Se application level, but this increase was decreased with prolonging the incubation periods from 15 to 30 days, while it was almost resembling at periods of 45 to 60 days.

Finally, with concern to the interaction between all of Se, $\mathrm{P}$ and time, results revealed that available $\mathrm{P}$ was positively correlated with both Se and $\mathrm{P}$ but negatively affected as the time of incubation was increased. These are similar to those of El-Ghanam, (2004) who reported that soil available $P$ was markedly increased with increasing $\mathrm{Se}$ and $\mathrm{P}$ application levels, but this increase was decreased with time prolonging the incubation periods from 15 to 30 days; where the reduction percentage caused by prolonging time from 15 to 30,30 to 45 and 45 to 60 days were $6.43,12.06$ and $10.46 \%$, respectively. 
Table (3). Soil available $\mathrm{P}\left(\mathrm{mg} \mathrm{kg}^{-1}\right)$ as affected by selenium and phosphorus application rates as well as incubation periods.

\begin{tabular}{|c|c|c|c|c|c|c|c|}
\hline \multirow{2}{*}{$\begin{array}{l}\text { Phosphorus rates } \\
\qquad\left(\mathrm{mg} \mathrm{kg}^{-1}\right)\end{array}$} & \multirow{2}{*}{$\begin{array}{l}\text { Selenium rates } \\
\qquad\left(\mathrm{mg} \mathrm{kg}^{-1}\right)\end{array}$} & \multicolumn{6}{|c|}{$\begin{array}{c}\text { Soil (1) Sandy } \\
\text { Time }\end{array}$} \\
\hline & & $\mathrm{T} 1$ & $\mathrm{~T} 2$ & T 3 & $\mathrm{~T} 4$ & T 5 & Mean \\
\hline \multirow{4}{*}{ P $1(0.00)$} & Se $1(0.0)$ & 6.80 & 6.40 & 6.00 & 6.40 & 6.40 & 6.40 \\
\hline & Se $2(0.5)$ & 6.80 & 6.40 & 6.00 & 6.00 & 6.40 & 6.32 \\
\hline & Se $3(1.0)$ & 7.20 & 6.40 & 6.00 & 6.40 & 6.00 & 6.40 \\
\hline & $\mathrm{Se} 4(2.0)$ & 7.60 & 6.40 & 6.00 & 6.40 & 6.20 & 6.44 \\
\hline \multicolumn{2}{|c|}{ Mean } & 7.10 & 6.40 & 6.00 & 6.30 & 6.20 & \\
\hline \multicolumn{2}{|c|}{ Grand mean of phosphorus rates } & 6.50 & & & & & \\
\hline \multirow{4}{*}{ P 2 (3.225) } & Se $1(0.0)$ & 7.60 & 6.80 & 6.40 & 6.00 & 6.40 & 6.64 \\
\hline & Se $2(0.5)$ & 7.60 & 6.80 & 6.00 & 6.40 & 6.80 & 6.72 \\
\hline & Se $3(1.0)$ & 8.80 & 7.60 & 6.80 & 6.40 & 6.80 & 7.28 \\
\hline & $\mathrm{Se} 4(2.0)$ & 9.20 & 8.00 & 7.20 & 6.40 & 7.60 & 7.68 \\
\hline \multicolumn{2}{|c|}{ Mean } & 8.30 & 7.30 & 6.60 & 6.30 & 6.90 & \\
\hline \multicolumn{2}{|c|}{ Grand mean of phosphorus rates } & 7.08 & & & & & \\
\hline \multirow{4}{*}{ P $3(6.45)$} & Se $1(0.0)$ & 8.00 & 7.20 & 6.80 & 6.40 & 6.80 & 7.04 \\
\hline & Se $2(0.5)$ & 9.20 & 8.40 & 7.60 & 6.80 & 7.20 & 7.84 \\
\hline & Se $3(1.0)$ & 11.2 & 10.0 & 9.20 & 8.40 & 9.20 & 9.60 \\
\hline & $\operatorname{Se} 4(2.0)$ & 11.6 & 10.4 & 9.30 & 8.40 & 8.80 & 9.71 \\
\hline \multicolumn{2}{|c|}{ Mean } & 10.0 & 9.00 & 8.23 & 7.50 & 8.00 & \\
\hline \multicolumn{2}{|c|}{ Grand mean of phosphorus rates } & 8.55 & & & & & \\
\hline \multirow{4}{*}{ P 4 (12.9) } & Se $1(0.0)$ & 8.80 & 8.00 & 7.60 & 7.20 & 6.80 & 7.68 \\
\hline & Se $2(0.5)$ & 10.0 & 9.20 & 8.40 & 7.60 & 7.60 & 8.56 \\
\hline & Se $3(1.0)$ & 12.4 & 11.2 & 9.20 & 8.70 & 9.60 & 10.2 \\
\hline & $\operatorname{Se} 4(2.0)$ & 13.2 & 11.2 & 9.60 & 8.80 & 9.20 & 9.80 \\
\hline \multicolumn{2}{|c|}{ Mean } & 11.1 & 9.90 & 8.70 & 7.30 & 8.30 & \\
\hline \multicolumn{2}{|c|}{ Grand mean of phosphorus rates } & 9.07 & & & & & \\
\hline \multirow{2}{*}{\multicolumn{2}{|c|}{ Grand mean of selenium rates }} & Se 1 & Se 2 & \multicolumn{2}{|c|}{ Se 3} & \multicolumn{2}{|c|}{ Se 4} \\
\hline & & 6.94 & 7.36 & \multicolumn{2}{|c|}{8.42} & \multicolumn{2}{|c|}{8.45} \\
\hline \multicolumn{2}{|c|}{ Selenium rates $\left(\mathrm{mg} \mathrm{kg}^{-1}\right)$} & $\mathrm{T} 1$ & $\mathrm{~T} 2$ & $\mathrm{~T} 3$ & $\mathrm{~T} 4$ & \multicolumn{2}{|c|}{$\mathrm{T} 5$} \\
\hline \multicolumn{2}{|c|}{ Se $1(0.0)$} & 7.80 & 7.10 & 6.72 & 6.50 & \multicolumn{2}{|c|}{6.60} \\
\hline $\mathrm{Se}$ & & 8.40 & 7.70 & 7.00 & 6.70 & & \\
\hline $\mathrm{Se}$ & & 9.90 & 8.80 & 7.80 & 7.48 & & \\
\hline $\mathrm{Se}$ & & 10.4 & 9.00 & 8.03 & 6.75 & & \\
\hline Grand $\mathrm{m}$ & of time & 9.13 & 8.15 & 7.39 & 6.86 & & \\
\hline LSD & & & & & & & \\
\hline Seleniun & es $(\mathrm{Se})$ & & & & & & \\
\hline Phosphor & ates $(\mathrm{P})$ & & & & & & \\
\hline Interacti & Se x P) & & & & & & \\
\hline Tin & & & & & & & \\
\hline Interacti & Se x T) & & & & & & \\
\hline Interacti & $(\mathrm{P} \times \mathrm{T})$ & & & & & & \\
\hline Interaction & x $(\mathrm{x} T)$ & & & & & & \\
\hline
\end{tabular}

See footnotes of table (2) 
Table 3: con.

\begin{tabular}{|c|c|c|c|c|c|c|c|}
\hline \multirow{3}{*}{$\begin{array}{l}\text { Phosphorus rates } \\
\qquad\left(\mathrm{mg} \mathrm{kg}^{-1}\right)\end{array}$} & \multirow{3}{*}{$\begin{array}{l}\text { Selenium rates } \\
\quad\left(\mathrm{mg} \mathrm{kg}^{-1}\right)\end{array}$} & \multicolumn{6}{|c|}{ Soil (2) sandy clay loam } \\
\hline & & \multicolumn{6}{|c|}{ Time } \\
\hline & & $\mathrm{T} 1$ & T 2 & $\mathrm{~T} 3$ & $\mathrm{~T} 4$ & T 5 & Mean \\
\hline \multirow{4}{*}{ P $1(0.0)$} & Se $1(0.0)$ & 6.00 & 5.60 & 5.20 & 5.60 & 6.40 & 5.76 \\
\hline & Se $2(0.5)$ & 6.40 & 5.60 & 5.20 & 6.00 & 6.40 & 5.92 \\
\hline & Se $3(1.0)$ & 6.80 & 6.00 & 6.00 & 6.40 & 6.40 & 6.32 \\
\hline & $\mathrm{Se} 4(2.0)$ & 7.20 & 6.40 & 6.40 & 6.00 & 6.40 & 6.48 \\
\hline \multicolumn{2}{|c|}{ Mean } & 6.60 & 5.90 & 5.70 & 6.00 & 6.40 & \\
\hline \multicolumn{2}{|c|}{ Grand mean of phosphorus rates } & 6.12 & & & & & \\
\hline \multirow{4}{*}{ P $2(3.225)$} & Se $1(0.0)$ & 7.20 & 6.40 & 6.00 & 6.00 & 6.80 & 6.48 \\
\hline & $\operatorname{Se} 2(0.5)$ & 7.60 & 6.80 & 6.00 & 6.40 & 6.80 & 6.72 \\
\hline & Se $3(1.0)$ & 8.40 & 7.20 & 6.40 & 6.80 & 7.20 & 7.20 \\
\hline & $\mathrm{Se} 4(2.0)$ & 9.20 & 8.00 & 6.80 & 6.00 & 6.80 & 7.36 \\
\hline \multicolumn{2}{|c|}{ Mean } & 8.10 & 7.10 & 6.30 & 6.30 & 6.90 & \\
\hline \multicolumn{2}{|c|}{ Grand mean of phosphorus rates } & 6.94 & & & & & \\
\hline \multirow{4}{*}{ P3 (6.45) } & Se $1(0.0)$ & 7.60 & 6.80 & 6.40 & 6.00 & 6.80 & 6.72 \\
\hline & Se $2(0.5)$ & 8.80 & 7.60 & 6.80 & 6.40 & 7.20 & 7.36 \\
\hline & Se 3 (1.0) & 10.0 & 8.40 & 7.20 & 6.40 & 7.60 & 7.92 \\
\hline & $\mathrm{Se} 4$ (2.0) & 12.4 & 11.2 & 9.20 & 8.00 & 8.40 & 9.84 \\
\hline \multicolumn{2}{|c|}{ Mean } & 9.70 & 8.50 & 7.40 & 6.70 & 7.50 & \\
\hline \multicolumn{2}{|c|}{ Grand mean of phosphorus rates } & 7.96 & & & & & \\
\hline \multirow{4}{*}{ P 4 (12.9) } & Se $1(0.0)$ & 8.40 & 7.20 & 6.40 & 6.80 & 7.20 & 7.20 \\
\hline & Se $2(0.5)$ & 9.60 & 8.40 & 7.20 & 7.60 & 8.00 & 8.16 \\
\hline & Se $3(1.0)$ & 11.6 & 9.20 & 8.00 & 7.20 & 7.60 & 8.72 \\
\hline & $\mathrm{Se} 4$ (2.0) & 13.6 & 12.4 & 11.2 & 10.0 & 10.4 & 11.5 \\
\hline \multicolumn{2}{|c|}{ Mean } & 10.8 & 9.30 & 8.20 & 7.90 & 8.30 & \\
\hline \multicolumn{2}{|c|}{ Grand mean of phosphorus rates } & 8.90 & & & & & \\
\hline \multirow{2}{*}{\multicolumn{2}{|c|}{ Grand mean of selenium rates }} & Se 1 & Se 2 & \multicolumn{2}{|c|}{ Se 3} & \multicolumn{2}{|c|}{ Se 4} \\
\hline & & 6.54 & 7.04 & \multicolumn{2}{|c|}{7.54} & \multicolumn{2}{|c|}{8.80} \\
\hline \multicolumn{2}{|c|}{ Selenium rates $\left(\mathrm{mg} \mathrm{kg}^{-1}\right)$} & $\mathrm{T} 1$ & $\mathrm{~T} 2$ & T 3 & $\mathrm{~T} 4$ & \multicolumn{2}{|c|}{$\mathrm{T} 5$} \\
\hline \multicolumn{2}{|c|}{ Se $1(0.0)$} & 7.30 & 6.50 & 6.00 & 6.10 & & \\
\hline Se 2 & & 8.10 & 7.10 & 6.30 & 6.60 & & \\
\hline Se 3 & & 9.20 & 7.70 & 6.90 & 6.70 & & \\
\hline Se 4 & & 10.60 & 9.50 & 8.40 & 7.50 & & \\
\hline Grand me & of time & 8.80 & 7.70 & 6.90 & 6.73 & & \\
\hline & & & at $5 \%$ & & & & \\
\hline Selenium & tes $(\mathrm{Se})$ & & & & & & \\
\hline Phosphort & rates $(\mathrm{P})$ & & & & & & \\
\hline Interactio & Se $x$ P) & & & & & & \\
\hline Tim & & & & & & & \\
\hline Interactio & Se $x \mathrm{~T})$ & & & & & & \\
\hline Interactio & $(\mathrm{P} \times \mathrm{T})$ & & & & & & \\
\hline Interaction & x $\mathrm{P} \times \mathrm{T})$ & & & & & & \\
\hline
\end{tabular}

See footnotes of table (2) 
Table 3: con.

\begin{tabular}{|c|c|c|c|c|c|c|c|c|}
\hline \multirow{2}{*}{$\begin{array}{l}\text { Phosphorus rates } \\
\qquad\left(\mathrm{mg} \mathrm{kg}^{-1}\right)\end{array}$} & \multirow{2}{*}{$\begin{array}{l}\text { Selenium rates } \\
\quad\left(\mathrm{mg} \mathrm{kg}^{-1}\right)\end{array}$} & \multicolumn{7}{|c|}{$\begin{array}{c}\text { Soil (3) clay } \\
\text { Time }\end{array}$} \\
\hline & & $\mathrm{T} 1$ & $\mathrm{~T} 2$ & T 3 & $\mathrm{~T} 4$ & T 5 & & Mean \\
\hline \multirow{4}{*}{ P $1(0.00)$} & Se $1(0.0)$ & 15.60 & 15.20 & 16.00 & 15.20 & 15.60 & & 15.52 \\
\hline & Se $2(0.5)$ & 15.20 & 14.40 & 14.00 & 15.80 & 15.20 & & 14.92 \\
\hline & Se $3(1.0)$ & 15.20 & 14.40 & 14.00 & 14.80 & 15.20 & & 14.72 \\
\hline & $\mathrm{Se} 4(2.0)$ & 14.40 & 14.00 & 13.60 & 14.40 & 15.20 & & 14.32 \\
\hline \multicolumn{2}{|c|}{ Mean } & 15.10 & 14.50 & 14.40 & 15.05 & 15.30 & I & \\
\hline \multicolumn{2}{|c|}{ Grand mean of phosphorus rates } & 14.87 & & & & & & \\
\hline \multirow{4}{*}{ P $2(3.225)$} & Se $1(0.0)$ & 18.80 & 17.20 & 18.00 & 18.40 & 18.40 & & 18.16 \\
\hline & $\operatorname{Se} 2(0.5)$ & 18.00 & 16.80 & 17.60 & 18.00 & 18.40 & & 17.76 \\
\hline & Se $3(1.0)$ & 17.20 & 16.40 & 16.80 & 17.20 & 17.60 & & 17.04 \\
\hline & $\operatorname{Se} 4(2.0)$ & 16.40 & 15.60 & 16.40 & 16.80 & 17.20 & & 16.48 \\
\hline \multicolumn{2}{|c|}{ Mean } & 17.60 & 16.50 & 17.20 & 17.60 & 17.90 & & \\
\hline \multicolumn{2}{|c|}{ Grand mean of phosphorus rates } & 17.36 & & & & & & \\
\hline \multirow{4}{*}{ P3 (6.45) } & Se $1(0.0)$ & 19.60 & 18.80 & 18.40 & 18.80 & 18.80 & & 18.88 \\
\hline & $\operatorname{Se} 2(0.5)$ & 19.20 & 18.00 & 18.00 & 18.40 & 18.40 & & 18.40 \\
\hline & Se $3(1.0)$ & 18.00 & 17.20 & 16.80 & 17.60 & 18.00 & & 17.52 \\
\hline & $\mathrm{Se} 4(2.0)$ & 17.20 & 16.40 & 16.80 & 17.20 & 17.60 & & 17.04 \\
\hline \multicolumn{2}{|c|}{ Mean } & 18.50 & 17.60 & 17.50 & 18.00 & 18.20 & & \\
\hline \multicolumn{2}{|c|}{ Grand mean of phosphorus rates } & 17.96 & & & & & & \\
\hline \multirow{4}{*}{ P 4 (12.9) } & Se $1(0.0)$ & 21.20 & 19.20 & 18.80 & 18.80 & 19.20 & & 19.44 \\
\hline & Se $2(0.5)$ & 20.00 & 19.20 & 18.40 & 18.00 & 18.80 & & 18.88 \\
\hline & Se $3(1.0)$ & 19.60 & 18.80 & 18.00 & 18.40 & 18.80 & & 18.72 \\
\hline & $\mathrm{Se} 4(2.0)$ & 18.40 & 17.60 & 17.20 & 17.60 & 18.40 & & 17.84 \\
\hline \multicolumn{2}{|c|}{ Mean } & 19.80 & 18.70 & 18.10 & 18.20 & 18.80 & & \\
\hline \multicolumn{2}{|c|}{ Grand mean of phosphorus rates } & 18.72 & & & & & & \\
\hline \multirow{2}{*}{\multicolumn{2}{|c|}{ Grand mean of selenium rates }} & Se 1 & Se 2 & \multicolumn{2}{|c|}{ Se 3} & \multicolumn{3}{|c|}{ Se 4} \\
\hline & & 18.00 & 17.49 & \multicolumn{2}{|c|}{17.00} & \multicolumn{3}{|c|}{16.42} \\
\hline \multicolumn{2}{|c|}{ Selenium rates $\left(\mathrm{mg} \mathrm{kg}^{-1}\right)$} & $\mathrm{T} 1$ & $\mathrm{~T} 2$ & T 3 & $\mathrm{~T} 4$ & \multicolumn{3}{|c|}{$\mathrm{T} 5$} \\
\hline \multicolumn{2}{|c|}{ Se $1(0.0)$} & 18.80 & 17.60 & 17.80 & 17.80 & \multicolumn{3}{|c|}{18.00} \\
\hline Se 2 & $.5)$ & 18.10 & 17.10 & 17.00 & 17.55 & & 17.70 & \\
\hline Se 3 & $.0)$ & 17.50 & 16.70 & 16.40 & 17.00 & & 17.40 & \\
\hline Se 4 & 2.0) & 16.60 & 15.90 & 16.00 & 16.50 & & 17.10 & \\
\hline Grand me & of time & 17.75 & 16.83 & $16.80 \mathrm{~d}$ & 17.21 & & 17.55 & \\
\hline & & & LSD at $5 \%$ & & & & & \\
\hline Selenium & tes $(\mathrm{Se})$ & & & & & & & \\
\hline Phosphor & $\operatorname{rates}(\mathrm{P})$ & & & & & & & \\
\hline Interactio & $($ Se $x \mathrm{P})$ & & & & & & & \\
\hline Tim & $(\mathrm{T})$ & & & & & & & \\
\hline Interactio & $(\operatorname{Se} \times \mathrm{T})$ & & & & & & & \\
\hline Interactio & $(\mathrm{P} \times \mathrm{T})$ & & & & & & & \\
\hline Interaction & ex $\mathrm{P} \times \mathrm{T}$ ) & & & & & & & \\
\hline
\end{tabular}

See footnotes of table (2)

\section{Conclusion}

As a final massage, the further understanding of selenium behavior in soils to predict its availability for crops in different systems will be a significant approach in future studies to establish form and safe doses of Se to be added in fertilizers.

The obtained results support the idea that adding Se to the soil is a good strategy to increase Se levels in food crops (agronomic bio-fortification), especially when crops are grown in soils that have been cultivated over the time due to their low $\mathrm{Se}$ adsorption capacity.

\section{References}

Birringer, M.; Pilawa, S. and Flohe, L. 2002. Trends in selenium biochemistry. Nat. Prod. Rep. 19: $693-718$.

Eich-Greatorex, S.; Krogstad, T. and Sogn, T.A. 2010. Effect of phosphorus status of the soil on selenium availability. J. Plant Nutr. Soil Sci. 173: $337-344$.

El-Gala, A.M.; Eid, M.A. and Al-Shandoody, H.G. (1998). The effect of organic matter, sulfur and $\mathrm{Fe}$ application on the availability of certain nutrients in the soil of El-Dhahera area, Sultanat of Oman. Arab Univ. J. Agric. Sci., 6: 607 - 623. 
El-Ghanam, M.M.M. 2004. Interaction effect between phosphorus and selenium on their availability in soil and contents in soybean plants grown on alluvial clayey soil. Annals Agric. Sci. Moshtohor 42: 2075 - 2088.

El-Ramady, H.R.; Abdalla, N. and Alshaal, T. 2014. Selenium and nano-selenium in agro-ecosystems. Environ. Chem. Letters, 12: $495-510$.

Fleming, G.A. 1980. Essential micronutrients II: Iodine and selenium. In: Davies B. E. (Ed.) Applied Soil Trace Elements, John Wiley \& Sons 199 - 234.

Guo, L.; Jury, W.A.; Frankenberger, W.T. and Zhang, Y.Q. 2000. Characterizing kinetics of sequential selenium transformation in soil. J. Environ. Qual. 29: 1041-1048.

Hartikainen, H. 2005. Biogeochemistry of selenium and its impact on food chain quality and human health. J. Trace Elem. Med. Biol. 18: 309 - 318.

Jackson, M.L. 1973. "Soil chemical analysis". Prentice-Hall of India Private Limited, New Delhi.

John, M.K. 1970. Colorimetric determination of phosphorus in soil and plant materials with ascorbic acid. Soil Sci., 19: 214 - 220. Use of $\mathrm{NH}_{4} \mathrm{HCO}_{3}$-DTPA soil test to assess availability and toxicity of selenium to alfalfa plants. Commun. Soil Sci. Plant Anal., 11: 1147 - 1156.

Kabata- Pendias, A. 2001. Trace Elements in soils and plants. $3^{\text {rd }}$ ed., Boca Raton, FL: CRC Press, 241-252.

Kabata-Pendias, A. and Mukherjee, A.B. 2007. Trace elements from soil to human. Berlin: SpringerVerlag.

Kumpulainen, J.; Raittila, A.M.; Lehto, J. and Koivistoinen, P. 1983. Electrothermal atomic absorption spectrometric determination of selenium in foods and diets. J. Assoc. Off. Anal. Chem. 66: 1129 - 1135 .

Lessa, J.H.; Araujo, A.M.; Silva, G.N.; Guiherme, L.R. and Lopes, G. 2016. Adesorption-desorption reactions of selenium (VI) in tropical cultivated and uncultivated soils under Cerrado biome. Chem. 164: 271 -277.

Li, J.; Peng, Q.; Liang, D.; Liang, S.; Chen, J.; Sun, H.; Li, S. and Lei, P. 2016. Effects of aging on the fraction distribution and bioavailability of selenium in three different soils. Chemosphere 144: 2351-2359.
Lopes, G.; William, F. and Luiz, R. G. 2017. Selenium behavior in the soil environment and its implication for human health. Ciencia Agrotecnologia 41: 605-615.

Masanza, B.; Maida, J.H.A.; Chilimba, A.D.C.; Lowole, M.W. and Nalivata, P.C. 2016. Liming and selenium application impact on plant available selenium in selected soils of Malawi. J. Soil Sci. Environ. Mang. 7: 115 - 122.

Murphy, J. and Riley, J.P. 1962. A modified single solution method for the determination of phosphate in natural waters. Anal. Chem. Acta., 27: $31-36$.

Nakamaru, y.; Taqami, K. and Uchida, S. 2006. Effect of phosphate addition on the sorptiondesorption reaction of selenium in Japanese agricultural soils. Chem. 63: $109-115$.

Nakamaru, Y.M. and Sekine, K. 2008. Sorption behavior of selenium and antimony in soils as a function of phosphate ion concentration. Soil Sci. Plant Nutr. 54: 332 - 341.

Neal, R. H. and Sposito, G. 1989. Selenate adsorption on alluvial soils. Soil Sci. Soc. Amer. J. 53: $70-74$.

Page, A.L., R.H. Miller and D.R. Keeney. 1982. "Methods of Soil Analysis Chemical and Microbiological Properties SSSA Inc., Mad., WI., USA.

Sadzawka, A.; Carrasco, M.; Grez, R. and Mora, M.L. 2004. Métodos de análisis recomendados para los suelos chilenos. Comisión de Normalizacióny Acreditación (CNA) de la Sociedad Chilena de la Ciencia del Suelo. 113 p.

Soltanpour, P.N. and Workman, D.N. 1980. Use of $\mathrm{NH}_{4} \mathrm{HCO}_{3}$-DTPA soil test to assess availability and toxicity of selenium to alfalfa plants. Commun. Soil Sci. Plant Anal., 11: 1147 - 1156.

Vouri, E.; Vaariskoski, J.; Hartikainen, H.; Vakkilatnen, P.; Kumpulatnen, J. and Nttnlvaaraa, K. 1989. Sorption of selenate by Finnish agricultural soils. Agric. Ecosyst. Environ. 25: $111-118$.

Walkley A. and Black, I.A. 1934. An examination of the degtjareff method for determining soil organic matter and a proposed modification of the chromic acid titration method' Soil Sci. 37: 29 38 . 


\section{تأثير التداخل بين الفوسفور والسيلينيوم المضافين مع الوقت علي تيسرهم في ثلاث أنواع مختلفة من الأراضي.}

$$
\begin{aligned}
& \text { "هبه عبد الحميد محمد أبوزيد ** حسن حمزة عباس ** محمد السيد علي" عصام الدين عبد العزيز محمد } \\
& \text { "معهز بحوث الأراضي والمياه والبيئه - مركز البحوث الزراعية - الجيزة - مصر . } \\
& \text { | |قسم الأراضي والمياه - كلية الزراعه بمشتهر -جامعة بنها- مصر. }
\end{aligned}
$$

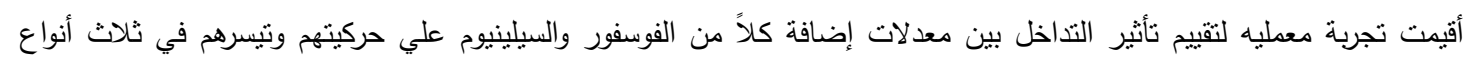

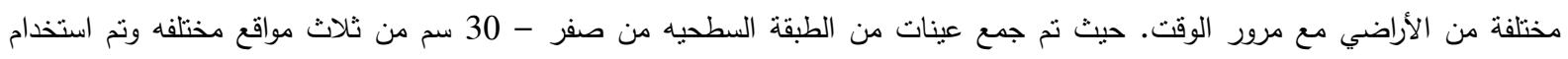

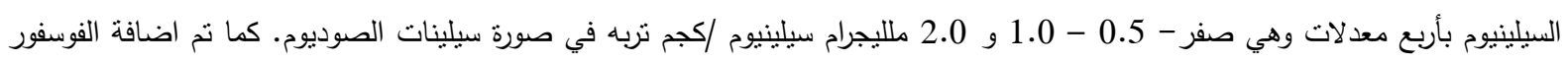

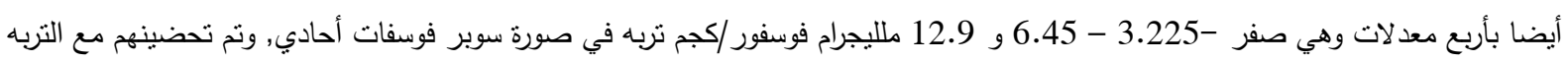

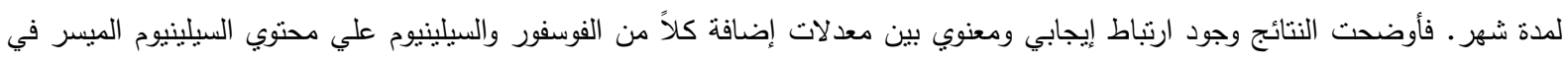

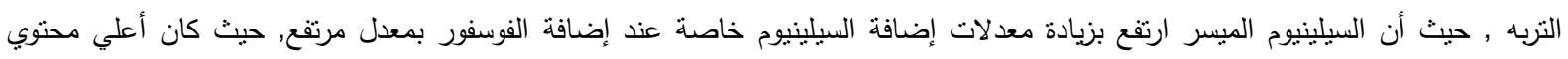

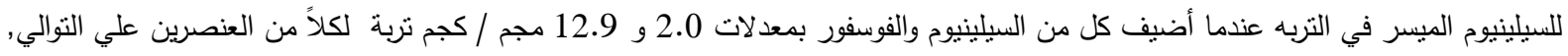

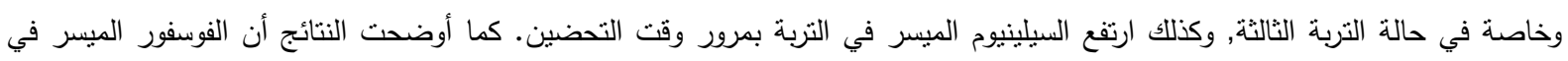
التزبه ارتفع أيضا بزيادة معدل إضافة العنصرين كما في حالة السيلينيوم ولكنه نأثر سلبيا بمرور الوقت. 